\title{
ディジタル計測の単発波形パラメータの測定精度
}

$$
\begin{aligned}
& \text { 正員道下幸志 (東京大) } \\
& \text { 正員河村達 雄 (東京大) } \\
& \text { 正員石井勝 (東京大) }
\end{aligned}
$$

\section{Accuracy of Waveform Parameters in Digital Measurement of Single-Shot Waveforms}

Koji Michishita, Member, Tatsuo Kawamura, Member, Masaru Ishii, Member (University of Tokyo)

In high voltage measurement digital measuring system is widely used for its attractive features, for example automatic data acquisition. However, the accuracy in the measurement of both the amplitude and time parameters by digital measuring system is not known in detail, especially in the measurement of single-shot waveforms.

In this paper, the accuracy of the peak value and the virtual front time of the standard lightning impulse without any signal processing of raw data is shown. From these results, the required characteristics for digital measuring system to satisfy the IEC Draft on digital recorders for measurement in high voltage impulse test techniques are shown. In addition, the accuracy of the peak voltage and the rise time of the Gaussian pulse is shown.

キーワード：サンプルレート, 分解能, ディジタイザ, 測定精度, 有効ビット数, A/D 変換

\section{1.まえがき}

近年，電力系統に扔ける送電電压の上昇，送電容量 の増大に伴って使用される電圧, 電流は増々高電圧, 大電流化の傾向にある。このため, 高電圧試験におけ る試験内容は複雑, 多岐となり，一層の信頼性が試験 に要求されるようになっている。高電圧試験の主要な 動向としては,

(i) 試験の自動化, 省力化

(ii) 試験の測定精度の向上

（iii） 試験結果の処理の自動化，効率化

などがあげられる。これらの目的に対し，ディジタル 計測は，極めて有力な手段であり，各所で大幅に取入 れられつつある。

高電圧現象は，一般に継続時間が極めて短く，統計 的なばらつきも多いため，信頼できる結果を得るため には, 一つの現象を確実に測定し，大量のデー夕を取 得する必要がある。更に試験によって得られた結果に
統計的検討を加える必要があり，自動計測の利点をも つディジタル計測システムは極めて有力な手段と なる。

また高電圧試験が生ずる偶発現象の測定や, 測定系 の応答を考慮した測定誤差の補正も可能であるなどの 利点を有している。

近年, 走查コンバータや直並列比較方式などの高速 $\mathrm{A} / \mathrm{D}$ 変換方式の進歩によって, サンプルレート (Sampling rate：サンプル時間間隔の逆数）は高速化 されつつある。また，大容量メモリーの開発による記 録時間の増大とも相まって,ディジタル計測の測定精 度は飛躍的に向上しつつある。

一方，ディジタル計測機器の対雑音性が高まり，高 電纴試験に特有の高磁界，高電界下の過酷な測定環境 においてもディジタル計測技術が盛んに適用されるよ うになった。

このような特徴をふまえてディジタル計測技術は， 研究開発はもとより高電圧機器のルーチン試験, フィ 
ールドにおけるサージ測定や雷観測など広い範囲にわ たって適用されている。

ディジタル計測システムの测定精度の把握に関連し て, 高電圧の分野で， $\mathrm{A} / \mathrm{D}$ 変換に伴う誤差に関す る研究が行われてきた。ディジタル計測システムで は, オシロスコープのアナログ出力を $\mathrm{A} / \mathrm{D}$ 変換して 記録するディジタイザが一般に利用される。ディジタ イザの垂直軸分解能はビット数 $(n)$ で表記され，フル スケールの電圧を $1 / 2^{n}$ に等分化することを意味する(1)。 $\mathrm{A} / \mathrm{D}$ 変換に伴う謓差の評価は, 各メーカごとに多く つ試験が行われている(2)。これらの試験のうち, 正弦 波や三角波といった繰返し波形を入力波形とし， $\mathrm{A} / \mathrm{D}$ 変換後のデータとの差を求め, その実効值を量 子化誤差のみの場合の実効值と比較することによって 得られる有効ビット数 (Effective number of bits) が ティジタイザの実質的な分解能の表記形式の一つとし て知られている( ${ }^{(3)}$ 。しかし，有効ビット数を求める力 ーブフィッティングに関しても規格化された試験法は なく、メーカによってその試験法は異なっており，ま た測定上十分な情報はメーカのカタログデータからは 得られない。

特に高電圧測定においては，標準雷インパルスなど の単発波形の測定行う場合が多く、ディジタル測定 システムの単発波形測定時の特性の把握を行う必要が ある。試験波形の多様性加ら，正弦波の周波数や直線 上昇波の攧きなどの一般性をもつパラメータを基に， 単発波形に対するディジタイザの特性を推定すること が望ましい。単発波形測定時の最大誤差の把握を行う こと㟍小限必要なことであり，この目的に対して は, 誤差の標準偏差を求妨ことによって統計的な性 貿加最大誤差が求められる利点をもつ標準偏差を用

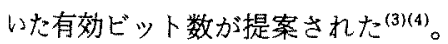

近年，単発波形に対するディジタイザの誤差評価法 も検討され，その結果，単発波形に対するディジタイ ザの特性は，入力波形の傾きおよびディジタルコード 依存することがわかった ${ }^{(5)}$ ここの結果から，ディジ タイザの特性評価を傾き掠よびディジタルコードに対 して行い,これらをパラメータとした有効ビット数の 提案当行われている(6)。

一方で標準雷インパルスの各波形パラメータに関す る測定精度の研究も進められている。これらの研究に おいては, 分圧器の出力を $\mathrm{A} / \mathrm{D}$ 変換する方式を用い た测定システムを前提に国内, CIGRE Study Comitee No. 33 Working Group 33-03 “高電圧試験および 則定技術”で論議されており，この方式での規格化が 見在IECで検討されている(1)。しかし従来の研究で
は, 電圧值バラメータに関してはディジタイザの垂直 軸分解能のみに基づいて，また時間パラメータに関し てはサンプルレートのみを基に検討されていた(7)。

本論文においては, 高電圧試験でよく用いられる標 準雷インパルス，およびアナログ回路の帯域試験でし ばしば用いられるガウシアンパルスの波形パラメータ の測定精度を、ディジタイザの出力データに処理を加 えない生デー夕（Raw data：以後単に生データと呼 ぶ）を用いた場合について，ディジタル計測システム の垂直軸分解能およびサンプルレートを基にして求め た。また，ディジタル計測を用いた際の波高值拉よび 規約波頭長の測定精度に関する検討から，現在の IEC 規格で要求されるディジタイザの性能について検討 した。

\section{2. 波形パラメータの測定精度の理論的検討}

高電圧試験でしばしば用いられる標準雷インパルス は，(1)式で表される。

$$
V(t)=e^{-a t}-e^{-b t}
$$

$a$ の逆数が $70 \mu \mathrm{s}, b$ の逆数が $0.4 \mu \mathrm{s}$ の場合には, 規約波頭長 $1.2 \mu \mathrm{s}$, 規約波尾長 $51 \mu \mathrm{s}$ の雷インパルス を与关る。（1）式のピークを与える時間 $t_{\max }$ は，時間

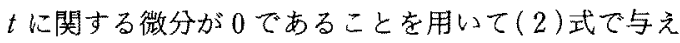
られる。

$$
t_{\max }=\{\log (b)-\log (a)\} /(b-a)
$$

垂直軸分解能が $n$ ビットのとき，(2)式を(1) 式 に代入して得られる波高点 $V\left(t_{\max }\right)$ がディジタイザの フルスケール (Full scale) に等しくなるように(3) 式のように $A$ を選ぶ。

$$
A=2^{n} / V\left(t_{\max }\right)
$$

$A$ と $V(t)$ の積で与えられる(4)式のインパルスに ついて以下では検討を行う。

$$
f(t)=A V(t)
$$

波高值が，ディジタイザのフルスケールに満たない 波形に対しては, ディジタイザの垂直分解能の減少と みなして評価を行うことができる。

生データを用いた場合のディジタル計測の測定精度 を考える場合には，A/D変換に伴う誤差が量子化誤 差のみの理想的なディジタイザについて考える。この 場合のディジタル計測システムの測定䛩差要因は, 以 下のように分類される。

（1）サンプル時間間融が, 有限である。サンプル 時間間隔が無限小の場合が；アナログ計測であると考 えることができる。

（2）電圧值方向の分解能が有限である。この場合 
アナログ計測においては，分解能が無限大であるとし て考えることができる。

$\langle 2 \cdot 1\rangle$ 波高值の測定精度 サンプル時間間隔が 有限であることを考慮した場合には，測定誤差が最大 となる波高值を气え時間 $t_{0}$ は， $t_{0}$ と $t_{0}+\Delta T$ におけ る(4)式の值が等しいことを条件に(5)式で与えら れる。

$$
\begin{aligned}
& t_{0}=\left\{\log \left(1-e^{-a \Delta T}\right)-\log \left(1-e^{-b \Delta T}\right)\right\} /(a-b) \\
& \text {............................ (5) } \\
& \text { ここに, } \Delta T \text { : サンプル時間間隔 }
\end{aligned}
$$

(5)式を(4)式に代入すると, 測定誤差が最大とな る波高値 $p_{u}$ は，(6) 式で与えられる。

$$
p_{L}=f\left(t_{0}\right) \cdots
$$

(6) 式から上記二つの誤差分類の内サンプル時間間 隔が有限であることに伴う波高值の測定精度が評価で きる。更に，量子化愦差が加わってディジタル計測に 用いた場合の波高值 $V_{D \max }$ は (7)式で与えられる。

$$
V_{D \max }=\left[f\left(t_{0}\right)\right] \cdots
$$

(7)式に乱いて $[x]$ はガウスの関数であり， $x$ を超え ない最大の整数を示す。

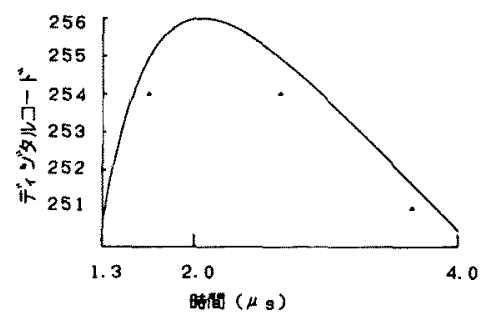

図 1 雷インパルスの波高点近傍のアナログ 波形と 8 ビット, $1 \mathrm{MHz}$ で測定した ディジタル波形

Fig. 1. Lightning impulse waveform around crest point in analog (real line) and digital $(\Delta)$ measurement ( 8 bits, $1 \mathrm{MHz}$ ).

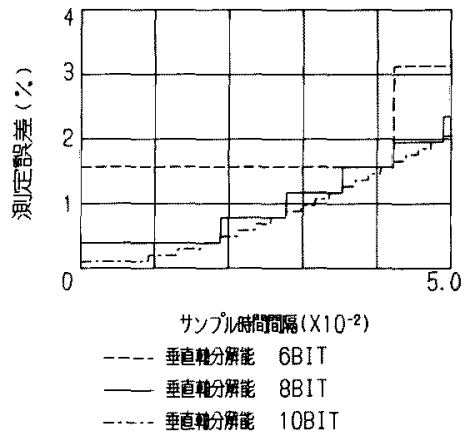

図 2 雷インパルス波形の波高值の測定精度

Fig. 2. Accuracy of the crest value of lightning impulse.
図1に波高点付近のアナログ波形とディジタル計測 システムを用いた場合の例を示す。サンプル時間間瓶 が大きくなると，波高值の測定誤差は 1 LSB (Least significant bit）を超えるようになり，波高值の測定 詰差は大きくなることがわかる。このことから，波高 值の測定精度がディジタイザの垂直軸分解能およびサ ンプルレートの両者に依存することがわかる。

図 2 に波高值の測定精度を示す。図の水平軸は, 規 約波尾長(Time to half-value)で規格化して示してい る。標準雷インパルス波形については, 波頭長に対し て $\pm 30 \%$ ，波尾長に対して $\pm 20 \%$ ，波高值に対して土 $3 \%$ 裕度が定められている(8)。このため表記に一般 性をもたせるためには，規格化を行う必要があり，波 高值の測定精度は波高点以降の緩やかな波尾に大きく 依存するため，規約波尾長で規格化を行った。サンブ 儿時間間隔が長くなると（6)式で与えられる波高值の 測定誤差涂々に大きくなるが, ディジタイザを用い た場合には, 測定誤差が 1 LSB 以下の範囲では, (7)式で与えられる波高值の測定誤差は, 一定值であ る。また, 同一のサンプル時間間隔に対して, 垂直軸 分解能の増大によって測定精度が改善されない場合も ある。例えば，ビット数が 1 ビット増加した場合に は, 増加前の 1 LSB を更に 2 分割することになり, 增加前の( 6 )式にお讨る測定誤差が, 1/2 LSBより 大きく 1 LSB 以下の場合には, 增加後の(6)式の測 定誤差は, 1 LSB より大きく2 LSB 以下となる。こ の結果, 測定誤差を図2のように分解能に対する割合 で示した場合，改善は見られない。

〈2・2〉 規約波頭長の測定精度＼cjkstart標準雷インパル スの時間パラメータとしては, 規約波頭長, 規約波尾 長があげられる。一般に测定時間長 $T_{x}$ が短いもの を, 同じサンプル時間間隔扝よび垂直軸分解能で測定 した場合には，測定精度を保つことが難しいことか ら，規約波頭長に関する測定精度の検討を行った。

標準雷インパルスの規約波頭長は，インパルスの波 高值の $30 \%$ $90 \%$ の時間長を0.6で除したもの (1.67 倍) として定義されている( ${ }^{(8)}$ 。

図 2 に示すように, 測定された波高值が既に誤差を 含んでおり，この結果 $30,90 \%$ 波高点もディジタル 計測とアナログ計測では, 図 3 に示されるように一致 しない。90\%波高点に扔いて $30 \%$ 波高点よりも誤差 が大きくなる。更にディジタイザによって割当てられ るディジタルレベルは，量子化䛊差が更に加わるため に 30，90\%波高点と一致するわけではない。このた め, 生データを用いた場合の測定時間長 $T$ は，見掛 け上 $30 \%$ レベルを上回り，かつ90\%レベルを超える 


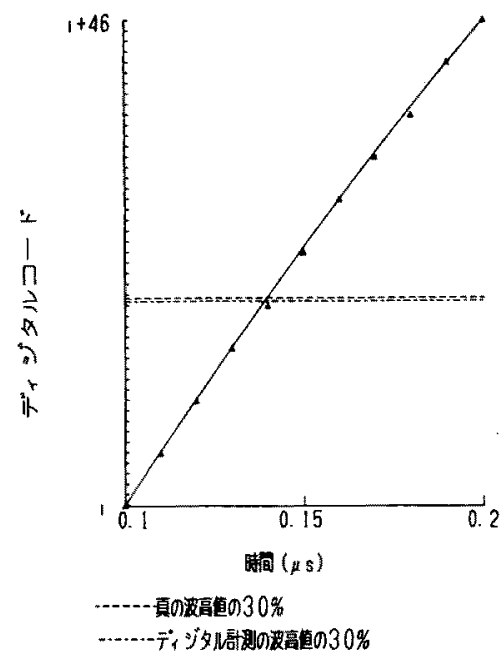

(a)

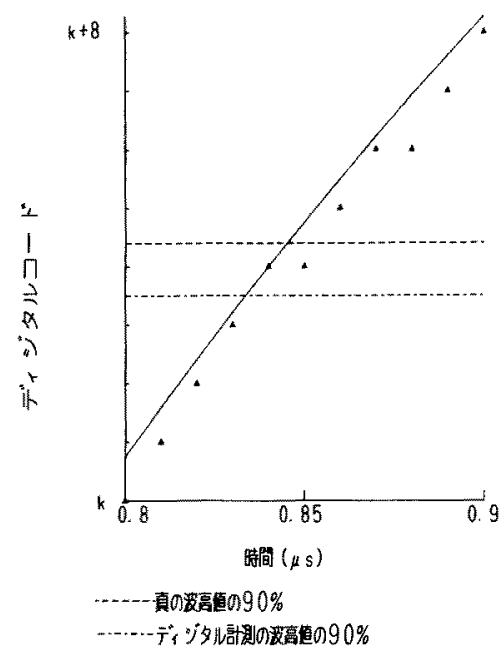

(b)

図 3 雷インパルスの $30 \%$ 波高点近傍 (a) および $90 \%$ 波高点近傍(b)0アナログ波形（実線） とディジタル波形 $(\Delta: 8$ ビット, $10 \mathrm{MHz})$ Fig. 3. Lightning impulse waveform around $30 \%(\mathrm{a})$ and $90 \%(\mathrm{~b})$ of peak value in analog (real line) and digital $(\Delta)$ measurement ( 8 bits, $10 \mathrm{MHz}$ ).

直前までの時間となる。

以上の結果として，真の波高値に対する $30 \sim 90 \%$ の時間長 $T_{x}$ とディジタル計測を用いた場合に測定 される波高值に対する30 90\%の時間長 $T$ は異 なる。

波高值の测定精度が 1 LSBの場合の Tの $T_{x}$ に対

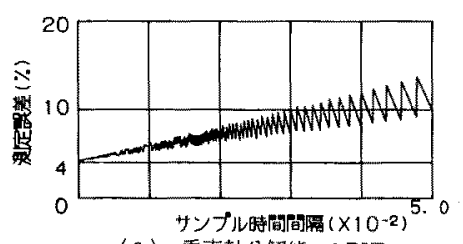

(a) 垂面軸分能能: $6 \mathrm{BIT}$

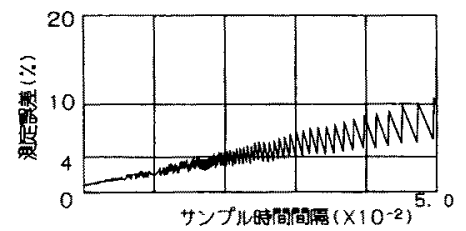

(b) 莗面軸分解能：8 BIT

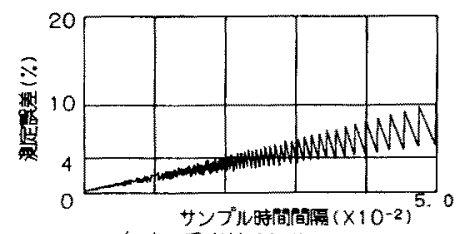

(c) 軸分解能: $10 \mathrm{BIT}$

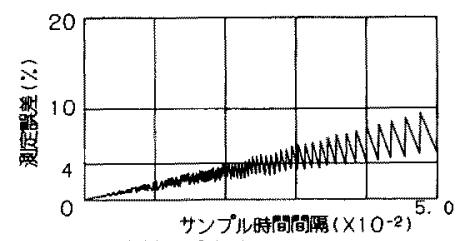

(d) 朝分解能：12 BIT

図 4 雷インパルスの規約波頭長の測定精度 Fig. 4. Accuracy in the measurement of virtual front time of lightning impulse.

する誤差率は，6ビットの場合 $4.2 \% ， 8$ ビットの場 合 $0.8 \%, 10$ ビットの場合 $0.3 \%, 12$ ビットの場合 $0.05 \%$ あった。

更に, $T$ をサンプル時間間隔 $\Delta T$ で測定する場合 には，その時間長内に含まれるサンプル点数は，サン ブル点の変化に伴って(8)式の $N_{s 1}$ または（9)式 $N_{s 2}$ で表される。

$$
\begin{aligned}
& N_{s 1}=[T / \Delta T]+1 \\
& N_{s 2}=[T / \Delta T] \cdots
\end{aligned}
$$

この結果, (8)式に対応する時間長 $t_{d 1},(9)$ 式に 対広する時間長 $t_{d 2}$ 咕，それぞれ(10)，(11)式で与え られる。

$$
\begin{aligned}
& t_{d 1}=[T / \Delta T] \Delta T \ldots \ldots . \\
& t_{d 2}=([T / \Delta T]-1) \Delta T
\end{aligned}
$$

(10)，(11)式を比較した場合には，Tが $T$ よりも 短くなることから，(11)式の㑚定䛇差が大きくなる。 また，(10)，(11)式よりサンプル時間 $\Delta T$ について， (12)式が成立しているとにに時間長の測定誤差は最も 
小さくなる。

$$
\Delta T=T / n
$$

ただし， $n:$ 正の整数

図 4 に生データを用いた場合の規約波頭長の測定誤 差の最大值を示す。水平軸は真の波高値に対する 30 90\%の時間長 $T_{x}$ で規格化されている。波高値の 測定精度とは異なり，(11)式で示される変化をする。

\section{IEC 規格原案を満たすのに要求される ティジタイザの性能}

現在，各国で検討されているIEC 規格に関する原 案 (1)では，ディジタイザに波高値に対して $2 \%$ ，時間 パラメータには 4\%以内の測定誤差を生データ（Raw data）で要求しており，それを実現するために必要 な性能を表 1 のうに規定している(9)。

雷インパルスに関しては，規約波頭長 $1.2 \mu \mathrm{s}$ ，規約 波尾長 $50 \mu \mathrm{s}$ のものを標準波形として抢り $1.2 \times 50 \mu \mathrm{s}$ と表記している。標準雷インパルスに対する，波頭 長, 波尾長の裕度の範囲内で, 測定上最も困難な波形 は, $0.84 \times 40 \mu \mathrm{s}$ となる。この場合について, 図 3 お 上び図 4 から，IEC 規格原案 ${ }^{(1)}$ が要求する各パラメー 夕に関する精度を満たすためのディジタイザの性能に ついて知ることがでるる。波高値測定に関して $2 \%$ 以

表 1 IEC 規格原案で要求されている

$$
\text { ディジタイザの性能 }
$$

Table 1. Characteristics of digital mea-

\begin{tabular}{|c|c|}
\hline 項目 & 必慗性能 \\
\hline サンブルレート & $30 / T_{x}, 8 f_{\max } 以 上$ \\
\hline 定格分解能 & $\begin{array}{l}0.4 \% \mathrm{fsd}\left(2^{-8}\right) \text { 以上 } \\
0.2 \% \mathrm{fsd}\left(2^{-9}\right) \text { 以上(波形比較の封) }\end{array}$ \\
\hline $\begin{array}{r}\text { 非棺線性 電厈軸 } \\
\text { 時間軸 }\end{array}$ & 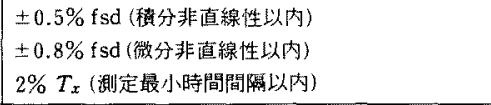 \\
\hline $\begin{array}{l}\text { インパルススタール } \\
\text { ファタタ }\end{array}$ & 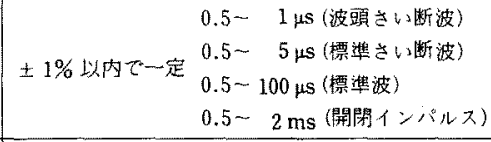 \\
\hline 立上り時間 & 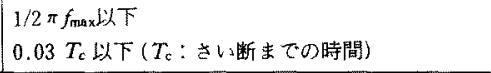 \\
\hline 内部雑音レヘル & $\begin{array}{l}0.4 \% \mathrm{fsd} \text { 以下 (原案 } 0.5 \% \text { fsd }) \\
0.1 \% \mathrm{fsd} \text { 以下 (波形比較0と类) }\end{array}$ \\
\hline 蔌意跟界 & $1 \%$ 以内(測定层副に対し) \\
\hline 電力周波数効果 & $0.5 \% \mathrm{fsd}$ \\
\hline $\begin{array}{cc}*: 0.5 \% & T_{x} \sim 2 \% \\
0.5 \% & T_{x} \text { 以下 } \\
T_{x} & : \text { 测是 } \\
f_{\max } & : \text { 壾験回 } \\
\text { fsd } & : \text { full }\end{array}$ & 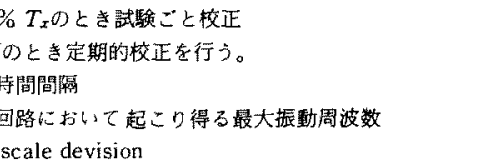 \\
\hline
\end{tabular}
suring system required in the IEC Draft.
内という精度を満たすためには, 垂直軸分解能が 6 ビットの場合には，規約波尾長に対して $4.2 \times 10^{-2}$ 倍以下のサンプル時間間隔が必要になる。同様にし て，垂直軸分解能が，8，10，12ビットの場合に対し て, 要求されるサンプル時間が図 3 から求められ，規 約波尾長が IEC 規格 ${ }^{(8)}$ の定める裕度 $\pm 20 \%$ 以内で最 短の $40 \mu \mathrm{s} の$ 場合については，(13)式を満たすサンプ ルレートが要求される。

$$
\begin{aligned}
& \text { サンプルレート } \geqq 592 \mathrm{kHz} \\
& \text { （垂直軸分解能：6ビット) } \\
& \text { サンプルレート } \geqq 510 \mathrm{kHz} \\
& \text { (垂直軸分解能：8-10 ビット) } \\
& \text { サンプルレート } 5007 \mathrm{kHz} \\
& \text { （垂直軸分解能：12 ビット） }
\end{aligned}
$$

一方，規約波頭長の測定の場合にも測定時間長 $T_{x}$ に対して 4\%以内の測定精度を満たすためには(14)式 のサンプルレートを満たす必要がある。IEC 規格 ${ }^{(8)} の$ 定める裕度 $\pm 30 \%$ 以内で最短の測定時間長 $T_{x}$ は, 標 準雷インパルスの 30 90\%の時間長 $(1.2 \mu \mathrm{s} \times$

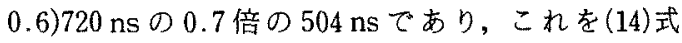
に代入すると各垂直軸分解能に対して必要なサンプル レートが(15)式のように与えられる。規格におけるサ ンプルレートの推奖值は，30/T $x$ である。これはサン プルレートのみを有限とし, 分解能が無限大と想定し たからである。

$$
\left.\begin{array}{c}
\text { サンプルレート } \geqq 56 / T_{x} \\
\text { (垂直軸分解能 }: 8 \text { ビット) } \\
\text { サンプルレート } \geqq 49 / T_{x} \\
\text { (垂直軸分解能 }: 10 \text { ビット) } \\
\text { サンプルレート } \geqq 49 / T_{x} \\
\text { (垂直軸分解能 }: 12 \text { ビット) }
\end{array}\right\}
$$

\section{4. ガウシアンパルスの測定精度}

ガウシアンパルスは，波形に対する定義が極めて明 確であり，アナログ回路の帯域の評価などに応用され ることが多々ある。このため，その波高值および立上 り時間の測定誤差の評価を行うことは実用上重要であ る。ガウシアンパルスの理論式は，(16)式で与えら れる。 


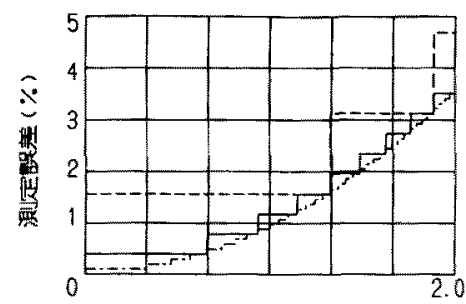

サンプルง

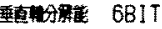

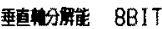

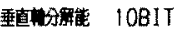

図 5 ガウシアンパルスの波高值の溳定精度 Fig. 5. Accuracy in the measurement of peak value of Gaussian pulse.

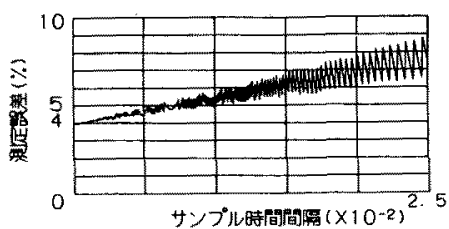

（a） 軸分解能：6 $\mathrm{BIT}$

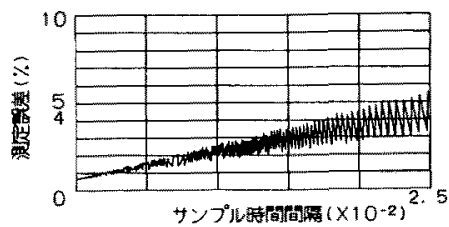

（b）真軸分解能：8 BIT

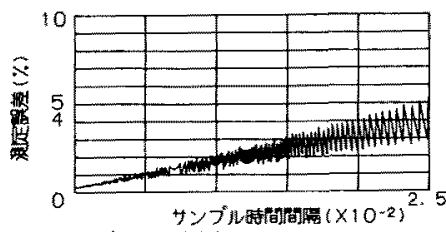

(c) 垂直軸分解能：10 BIT

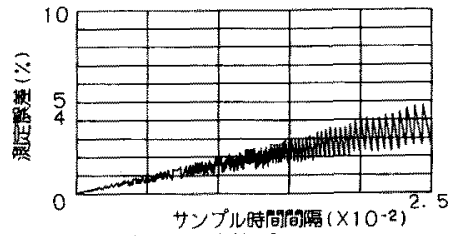

(d) 整直軸分解能：12 BIT

図 6 ガウシアンパルスの 10〜90\%立上り 時間の測定精度

Fig. 6. Accuracy in digital measurement of $10 \sim 90 \%$ rise time of Gaussian pulse.

$g(t)=A e^{-\pi t^{2} / r^{2}}$

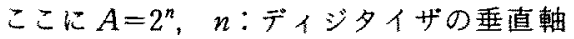
分解能

〈4・1〉 波高值の測定精度 雷インパルスの場合 と同様にして分解能が無限大でサンプル時間間隔が有
限な゙場合の，波高值を与える時間 $t_{0 g}$ は，(17)式で与 えられる。

$$
t_{0 g}= \pm \Delta t / 2
$$

(17)式を(16)式に代入することによって分解能が無 限大の場合の波高值が求まり, 分解能を考慮した場合 の波高值 $V_{d m g}$ は，(18)式で与えられる。

$$
V_{d m s}=\left[g\left(t_{0}\right)\right]
$$

（18）式を基に測定誤差を評価したのが図 5 である。

〈4・2〉立上り時間の測定精度 ガウシアンパル スの立上り時間は，波高値の $10 ， 90 \% の$ 時間で与え られる。雷インパルスの規約波頭長の場合と同様に， 〈4・1〉節に示した誤差を含むディジタル計測を用いた 際の波高值に対する $10 ， 90 \%$ は，真のガウシアンパ ルスの $10,90 \%$ とは異なる。更に量子化誤差の影響 のために真の立上り時間 $T_{x}$ とディジタル計測の場合 の測定時間 $T$ は異なる。図 6 に示されるサンプル時 間間隔が $0.025 T_{x}$ 以下の場合の，Tの $T_{x}$ 対対する 誤差率は， 6 ビットの場合 $3.9 \% ， 8$ ビットの場合 $0.7 \%, 10$ ビットの場合 $0.25 \%, 12$ ビットの場合 0.04\%で一定である。

時間パラメータに対する測定誤差の最大值の計算過 程は，標準雷インパルスの規約波頭長の場合と同様で ある。（8)〜(11)式を用いて，がウシアンパルスの立 上り時間の測定精度を求めたものを図6に示す。

\section{5. データ補正と測定精度}

以上の検討において，アナログ計測の場合の測定精 度として得られたものには, 読取り誤差が含まれてい ない。実際には，アナログ計測では，十分な精度を満 たしつつ，標準雷インパルスの規約波頭長と規約波尾 長のようなオーダの巽なる時間パラメータを測定する ためには，時間掃引速度を調整する必要があり，一台 の測定器による同時計測は困難である。

また高電圧計測においては，オシロスコープの読取 り誤差 3\%を許容しているが, ディジタル計測の場合

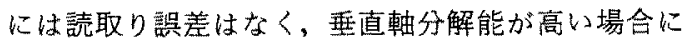
は，得られたデータの信頼性は非常に高い。

本論文において計算された生デー夕を用いた際の測 定精度は，最低限保証される測定精度であり，改善も 可能である。

実際に波形パラメー夕を求める際には，あてはめ (fitting) などのデータ処理を行う場合が多く, 簡単 なデー夕処理によっても測定精度は大きく向上 する(10)。

ブリトリガ機能や, 短いサンプル間隔での長時間に わたる現象の観測などアナログ計測に比べて多くの利 
点を有するディジタル計測は，高電圧計測のような偶 発現象の観測において，極めて有力である。

\section{6. 結 言}

（1）有効ビット数と垂直軸分解能が一致するよう な $\mathrm{A} / \mathrm{D}$ 変換に伴う誤差がないディジタイザにおける 標準雷インパルスに対する波頭長，波高値の測定精度 の評価を行った。

（2）波高值の測定精度は, 垂直軸分解能が一定の 堭合サンプル時間間隔に対してガウスの記号で表され る変化をすることがわかった。

（3）時間パラメータの測定精度は，ガウスの記号 で表される項と, サンプル時間間隔の積で表記される 変化をすることがわかった。

（4）現在, 審議中の IEC 規格草案で規定される ディジタイザに要求される性能について評価を行っ た。実質的に問題となるのは, 規約波頭長に要求され る測定精度 $4 \%$ であり, 波高値に対して要求される測 定精度 $2 \%$ ，規約波頭長に対して要求される測定精 度を満たす垂直軸分解能, サンプル時間間隔が実現さ れていれば，満たされることがわかった。

（5） 規約波頭長に要求される測定精度を満たすた めには, 垂直軸分解能が 8 ビットの場合には $112 \mathrm{MHz}$ 以上, 10 ビットから 12 ビットの場合には $98 \mathrm{MHz}$ 以 上のサンプルレートが必要なことがわかった。

(平成元年 9 月 27 日受付, 同 2 年 2 月 23 日再受付)

\section{文献}

(1) IEC 42 (Secreteriat) 55"Draft-Digital recorders for measurement in high-voltage impulse tests" (1989)

(2) 例えば, "Dynamic Performance Testing of A to D Converters", Hewlett Packard Product Note 5180A-2

(3) K. Schon, H. Korff \& R. Malewski : "On the Dynamic Characteristics of Digitizers for HV Impulse Measurement", 4th International Symposium on High-Voltage Engineering. Pa65, 05 (1983)

(4) R. Malewski, T. MCcomb \& M. Collins : "Measuring Properties of Fast Digitizers Employed for Recording HV Impulses", IEEE Trans. Instrum. Meas., IM-32, 17 (1983)

(5) T. Kawamura, M. Ishii \& K. Michishita: "Accuracy in Digital Measurement of Single-shot Waveform". Second International Conference on Properties and Application of Dielectric Materials, p. 303 (1988)

(6) K. Michishita, T. Kawamura \& M. Ishii : "Improved Method in Evaluating Dynamic Characteristics of Digitizers 6th International Symposium on High-Voltage Engineering, No. 42 (1989)

( 7 ) T. R. McComb \& R. Malewski : "Technical Basis of International and Electronics Engineering Inc. Standards on Digital Recorders for Measurement in HV Impulse Tests", 5th International Symposium on High-Voltage Engineering $\mathrm{Pa}$. 72. 01, 1987

(8) IEC Publication 60-2 "High-voltage test techniques" Part 2 (1973)

（9）原田・松本・道下・石井・河村：「インパルス試験用デイジタル レコーダに要求される性能について」, 平元電気学会全大, No. 1119

（10）道下・河村・石井：「単発波形のディジタル計測精度」，電気 学会放電高電圧合同研資, ED-87-95；HV-87-42（昭 62）

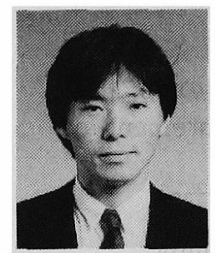

\section{道下幸 志 (正員)}

昭和 37 年 9 月 24 日生。 63 .年 3 月東京大学大学院工学系研究科電気 工学専攻修士課程修了。同年 4 月同 大学院博士課程進学, 現在に至る。 主として, 高電圧工学に関する研究に従事。

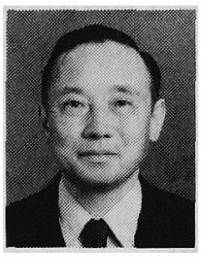

\section{河 村 達 雄 (正員)}

昭和 5 年 8 月 16 日生。 34 年 3 月 東京大学数物系大学院博士課程修 了。同年 4 月, 東京大学生産技術研 究所勤務。 37 年 1 月同助教授, 44 年 4 月同教授, 現在に至る。工学博士。電力工学, 高 電圧工学化関する研究に従事。 $46,48,59$ 年電気学 会進歩賞, 46 年 IEEE Power Engineering Society Prize paper Award, 51 年電気学会論文賞および電力 賞受賞。 43,44 年度電気学会東京支部評議員, 53 , 54 年度編修理事，60，61 年度副会長。電気設備学会 会長。電子情報通信学会, 応用物理学会, 電気設備学 会, IEEE, CIGRE 会員。

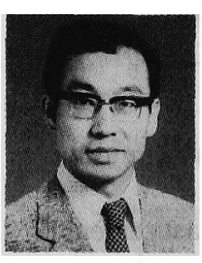

\section{石 井 勝 (正員)}

昭和 24 年 3 月 11 日生。 51 年 3 月東京大学大学院工学系研究科博士 課程修了。同年 4 月東京大学助教 授, 生産技術研究所勤務, 現在に至 る。工学博士。主として, 系統絶緑, 自然雷, 高電圧 現象の測定に関する研究に従事。平成元， 2 年度電気 学会東京支部評議員。IEEE Senior Member。 